\title{
A cost-effectiveness analysis of folic acid fortification policy in the United States
}

\author{
Tanya GK Bentley ${ }^{1, *}+$, Milton C Weinstein ${ }^{2}$, Walter C Willett ${ }^{3}$ and Karen M Kuntz ${ }^{2}$ \\ ${ }^{1}$ The Faculty of Arts and Sciences, Harvard University Ph.D. Program in Health Policy, 79 John F. Kennedy \\ Street, Cambridge, MA, USA: ${ }^{2}$ The Department of Health Policy and Management, Harvard School of Public \\ Health, Boston, MA, USA: ${ }^{3}$ The Departments of Epidemiology and Nutrition, Harvard School of Public Health, \\ Boston, MA, USA
}

Submitted 14 May 2007: Accepted 3 April 2008: First published online 1 July 2008

\begin{abstract}
Objective: To quantify the health and economic outcomes associated with changes in folic acid consumption following the fortification of enriched grain products in the USA.

Design: Cost-effectiveness analysis.

Setting: Annual burden of disease, quality-adjusted life years (QALY) and costs were projected for four steady-state strategies: no fortification, or fortifying with 140, 350 or $700 \mu \mathrm{g}$ folic acid per $100 \mathrm{~g}$ enriched grain. The analysis considered four health outcomes: neural tube defects (NTD), myocardial infarctions (MI), colon cancers and $\mathrm{B}_{12}$ deficiency maskings.

Subjects: The US adult population subgroups defined by age, gender and race/ ethnicity, with folate intake distributions from the National Health and Nutrition Examination Surveys (1988-1992 and 1999-2000), and reference sources for disease incidence, utility and economic estimates.

Results: The greatest benefits from fortification were predicted in MI prevention, with 16862 and 88172 cases averted per year in steady state for the 140 and $700 \mu \mathrm{g}$ fortification levels, respectively. These projections were between 6261 and 38805 for colon cancer and 182 and 1423 for NTD, while 15-820 additional $\mathrm{B}_{12}$ cases were predicted. Compared with no fortification, all post-fortification strategies provided QALY gains and cost savings for all subgroups, with predicted population benefits of 266649 QALY gained and $\$ 3.6$ billion saved in the long run by changing the fortification level from $140 \mu \mathrm{g} / 100 \mathrm{~g}$ enriched grain to $700 \mu \mathrm{g} / 100 \mathrm{~g}$.

Conclusions: The present study indicates that the health and economic gains of folic acid fortification far outweigh the losses for the US population, and that increasing the level of fortification deserves further consideration to maximise net gains.
\end{abstract}

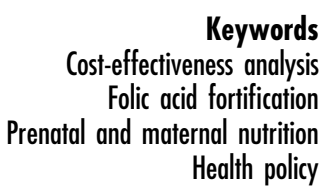

Increasing the intake of folate or folic acid during preconception and early in pregnancy can significantly reduce the risk of neural tube defects (NTD) in newborns ${ }^{(1,2)}$. Increased intake may also reduce the risk of myocardial infarction (MI) and colon cancer ${ }^{(3-16)}$ and increase the risk that symptoms of vitamin $\mathrm{B}_{12}$ deficiency are masked ${ }^{(4,5,7,12)}$, thereby allowing the neurological manifestations of the disease to progress ${ }^{(4)}$.

In 1998, the US Food and Drug Administration mandated that manufacturers add $140 \mu \mathrm{g}$ of folic acid per $100 \mathrm{~g}$ of enriched cereal-grain product ${ }^{(11,13,14)}$, and several studies have shown that such fortification provides substantial health and economic benefits ${ }^{(6,8,9,13,14,17-21)}$. However, the potential economic and health effects of

$\uparrow$ Correspondence address: RAND Corporation, 1776 Main Street, PO Box 2138, Santa Monica, CA 90407-2138, USA. this and alternative fortification policies have not been evaluated using national post-policy data adjusted for measurement error, while considering all four relevant health outcomes among population subgroups.

Accordingly, the present analysis quantifies the projected health and economic outcomes for NTD, MI, colon cancers and $\mathrm{B}_{12}$ maskings associated with the changes in folic acid consumption following fortification in the USA, as well as for alternative fortification levels.

\section{Methods}

\section{Overview}

Population-wide disease burden and the associated costs and quality-adjusted life years (QALY) were projected under four scenarios: no fortification, or fortification with 
140,350 or $700 \mu \mathrm{g}$ of folic acid per $100 \mathrm{~g}$ enriched grain. The no-fortification strategy reflects the pre-fortification levels of folate intake, the $140 \mu \mathrm{g}$ strategy reflects the current post-fortification intake in the USA, and fortifying with 350 and $700 \mu \mathrm{g}$ are hypothetical scenarios ${ }^{(13,19,20)}$. The four scenarios differ only in terms of the distribution of folate intake in the population, which we model in four categories: $\leq 200,201-300,301-400$ and $>400 \mu \mathrm{g} / \mathrm{d}$.

For each scenario, we projected the steady-state number of NTD, MI, colon cancers and $\mathrm{B}_{12}$ maskings among a US population of non-institutionalised, non-Hispanic white (heretofore referred to as 'white'), non-Hispanic black ('black') and Mexican-American persons aged 15 years or older. Other racial/ethnic subgroups were not included because of insufficient sample size on which to base folate intake estimates. For each folate intake category, we estimated age-, gender- and race/ethnicity-specific risks of developing each of the four health outcomes. We then assigned lifetime QALY losses and disease-related net costs for each health outcome, using either published estimates or a Markov modelling approach, to calculate the population-wide impact of each strategy.

\section{Folate intake distributions}

Estimates of population-based folate intake distributions were previously derived using food and dietary supplement data from two periods of the National Health and Nutrition Examination Surveys (NHANES) ${ }^{(22)}$. Briefly, data from NHANES III (1988-1994) were used to estimate prefortification food folate intake, and those from NHANES 1999-2000 were used to estimate both dietary supplement intake and post-fortification food folate intake. Because nutrient intake data are based primarily on one $24 \mathrm{~h}$ dietary recall measure, which does not represent an individual's average long-term daily intake, population distribution estimates of dietary folate intake were corrected for measurement error using a sub-sample of NHANES III subjects who had provided two $24 \mathrm{~h}$ recalls. Total folate intake distributions before and after the fortification policy, corrected for measurement error, are shown in Fig. 1 and in the Appendix. Folate intake for the two hypothetical scenarios was estimated as the product of the pre-post differences in corrected food folate intake and the ratio of the higher to the current levels (e.g. 350/140 for the $350 \mu \mathrm{g}$ strategy), plus the post-fortification supplement intake.

\section{Disease incidence}

Annual incidence of the four disease outcomes prior to fortification was estimated as a function of age range, gender and race/ethnicity (Table 1). When data were not available for the Mexican-American population, the rates for the Hispanic population were used.

All women between the ages of 15 and 44 years ${ }^{(23-26)}$ were considered at risk for an NTD-affected pregnancy. NTD incidence as a function of race/ethnicity was based on estimates from the Centers for Disease Control and
Prevention (CDC) of $10 \cdot 6$ cases of spina bifida and anencephaly per 10000 live births ${ }^{(9,27)}$. Live birth rates from the National Center for Health Statistics ${ }^{(28)}$ were used to calculate NTD incidence per 100000 women aged $15-44$ years.

MI incidence was based on calculations by gender and age from the Framingham Risk Equations ${ }^{(29)}$. The relative racial/ethnic distribution of MI incidence was assumed to be the same as that of CHD-specific death among each age and gender-specific subgroup ${ }^{(30)}$. Subgroup-specific annual colon cancer incidence rates were derived from the Surveillance, Epidemiology, and End Results Program (SEER) of the National Cancer Institute ${ }^{(31-33)}$.

Vitamin $\mathrm{B}_{12}$ masking was defined as the delayed diagnosis of $\mathrm{B}_{12}$ deficiency followed by the development of neurological complications. Estimates of masking risk incorporated the probability of consuming greater than $1000 \mu \mathrm{g}$ folate $/ \mathrm{d}^{(22)}$ - the 'tolerable upper intake level' for folic acid ${ }^{(10,11)}$ - and the risk of pernicious anaemia (PA) a common cause of $\mathrm{B}_{12}$ deficiency ${ }^{(19,34,35)}$.

Folate-specific incidence of each disease was calculated by using data on the percentage of the population in each folate intake category (Fig. 1) and the relative risks of disease by folate intake to split out the subgroupspecific disease rates. The risk of NTD was reduced by $50 \%$ for women with folate intake levels of greater than $400 \mu \mathrm{g} / \mathrm{d}^{(1,2,13,14,19,20)}$, and the relative reduction of MI risk for individuals with folate intake greater than $400 \mu \mathrm{g} / \mathrm{d}$ was $24 \%{ }^{(36)}$. The risk ratios for colon cancer diagnosis by folate intake were $0.92,0.79$ and 0.69 for 201-300, 301-400 and $>400 \mu \mathrm{g} / \mathrm{d}$, respectively, compared with $\leq 200 \mu \mathrm{g} / \mathrm{d}^{(37)}$. Relative risks for $\mathrm{MI}$ and colon cancer were assumed to be the same for men and women.

\section{Valuing outcomes}

The number of disease events associated with each strategy were estimated as the product of incidence and national population estimates for each subgroup ${ }^{(38)}$. The numbers of events were multiplied by the associated QALY lost and net costs per event (Table 2) to estimate the net health and economic impact of each fortification strategy. All QALY and cost estimates were discounted by $3 \%$ per year.

\section{Health related quality-of-life}

Estimates of QALY lost for NTD and $\mathrm{B}_{12}$ masking outcomes were based on a CDC cost-effectiveness analysis $^{(20)}$ that used the Quality of Well-Being Index ${ }^{(39)}$. To estimate the QALY lost associated with MI and colon cancer we used a Markov modelling approach in which we incorporated disease-specific mortality, health-related quality-of-life weights and mortality from other causes $^{(40-42)}$. For MI, we assumed the same utility for patients with coronary artery disease (CAD) of $0 \cdot 84$, calculated from previous analyses as the mean of mild and severe angina, weighted by the proportion of angina patients with $\mathrm{CAD}^{(43-45)}$. For colon cancer, life expectancy after 

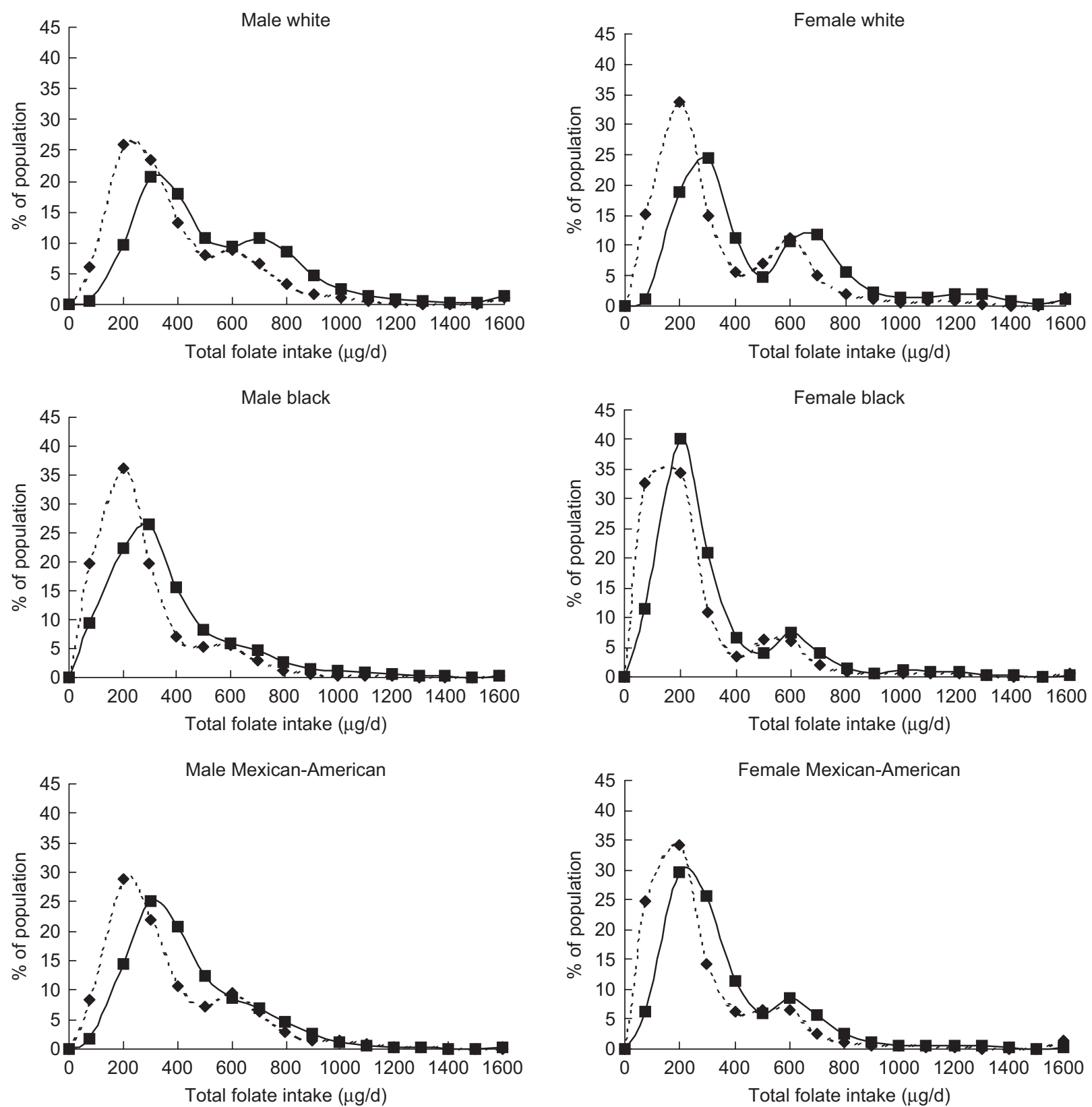

Fig. 1 Daily total folate intake distributions pre- $v$. -post fortification by gender and race/ethnicity, corrected for measurement error ( $\cdots$, pre; - - post). Reprinted with permission from the American Public Health Association from Bentley TGK, Willett WC, Weinstein WC and Kuntz KM. Population-level changes in folate intake by age, gender, and race/ethnicity after folic acid fortification ${ }^{(22)}$

diagnosis was weighted by stage-specific mortality and we assumed a stage-weighted utility of $0 \cdot 76^{(46)}$.

\section{Costs}

All costs were adjusted to 2005 dollars using the Consumer Price Index. For costs incurred with NTD, estimates from a published analysis ${ }^{(21)}$ were used, weighted for relative proportions of spina bifida and anencephaly ${ }^{(9)}$. Costs incurred with MI events incorporated short-term care ${ }^{(43)}$ as well as annual outpatient, medications and diagnostic costs for a typical CAD patient ${ }^{(45,47,48)}$, which were assumed to be applicable to MI patients. Costs incurred with colon cancer incorporated stage-weighted estimates from the Institute of Medicine ${ }^{(49-56)}$, and those associated with cases of masked $\mathrm{B}_{12}$ deficiency were based on calculations by the $\mathrm{CDC}^{(20)}$. Estimates of annual fortification costs for the $140 \mu \mathrm{g}$ fortification strategy ( $\$ 3 \cdot 3$ million) were based on those used by Grosse and colleagues ${ }^{(21)}$, and those for the two hypothetical scenarios $(\$ 6 \cdot 0$ and $\$ 10.6$ million for $350 \mu \mathrm{g}$ and $700 \mu \mathrm{g}$ fortification strategies, respectively) incorporated the fixed cost estimates from Grosse et al. and the CDC's estimates of bulk folic 
Table 1 Estimates of annual disease risk per 100000 persons*

\begin{tabular}{|c|c|c|c|c|c|c|}
\hline & \multicolumn{3}{|c|}{ Men } & \multicolumn{3}{|c|}{ Women } \\
\hline & Whitet & Blackt & Mexican-American & Whitet & Blackt & Mexican-American \\
\hline \multicolumn{7}{|c|}{ Neural tube defects } \\
\hline $15-44$ years & - & - & - & $6 \cdot 10$ & $4 \cdot 58$ & $13 \cdot 31$ \\
\hline \multicolumn{7}{|c|}{ Myocardial infarctions } \\
\hline 15-44 years & $60 \cdot 6$ & $89 \cdot 8$ & $23 \cdot 6$ & $19 \cdot 1$ & $50 \cdot 7$ & $6 \cdot 3$ \\
\hline $45-64$ years & $698 \cdot 3$ & $1100 \cdot 0$ & $449 \cdot 7$ & $349 \cdot 0$ & $918 \cdot 1$ & $253 \cdot 3$ \\
\hline $65+$ years & $1627 \cdot 7$ & $2047 \cdot 7$ & $1306 \cdot 8$ & $886 \cdot 3$ & $1363 \cdot 8$ & $759 \cdot 4$ \\
\hline \multicolumn{7}{|l|}{ Colon cancer } \\
\hline 15-44 years & $2 \cdot 98$ & $3 \cdot 13$ & $1 \cdot 96$ & $2 \cdot 21$ & $3 \cdot 70$ & $1 \cdot 47$ \\
\hline $45-64$ years & $48 \cdot 51$ & $59 \cdot 86$ & $24 \cdot 05$ & 34.53 & $49 \cdot 69$ & $20 \cdot 88$ \\
\hline $65+$ years & $247 \cdot 59$ & $222 \cdot 24$ & $147 \cdot 80$ & $199 \cdot 03$ & $230 \cdot 91$ & $96 \cdot 50$ \\
\hline \multicolumn{7}{|c|}{ Vitamin $\mathrm{B}_{12}$ masking $\ddagger$} \\
\hline 15-44 years & \multicolumn{3}{|c|}{0.012} & \multicolumn{3}{|c|}{0.029} \\
\hline $45-64$ years & \multicolumn{3}{|c|}{0.078} & \multirow{2}{*}{\multicolumn{3}{|c|}{$\begin{array}{l}0.185 \\
0.427\end{array}$}} \\
\hline $65+$ years & \multicolumn{3}{|c|}{$0 \cdot 181$} & & & \\
\hline
\end{tabular}

*Some age categories have been combined for ease of presentation.

tNon-Hispanic white and non-Hispanic black.

$\ddagger$ Annual rate of vitamin $B_{12}$ masking and pernicious anaemia and total folate intake $>1000 \mu \mathrm{g} / \mathrm{d}$.

Table 2 Net costs incurred and QALY lost associated with NTD, MI, colon cancer and vitamin $B_{12}$ masking events*

\begin{tabular}{|c|c|c|c|c|c|}
\hline \multirow[b]{2}{*}{ Disease outcome } & \multirow[b]{2}{*}{ Men } & \multirow[b]{2}{*}{ Women } & \multicolumn{2}{|c|}{ Ranges for sensitivity analyses } & \multirow[b]{2}{*}{ Source } \\
\hline & & & Men & Women & \\
\hline \multicolumn{6}{|r|}{ 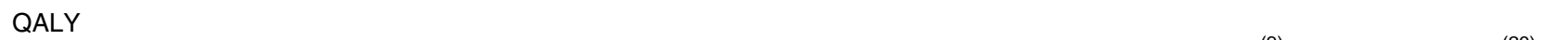 } \\
\hline NTD & - & $18 \cdot 91$ & - & $13 \cdot 0-28 \cdot 0$ & $\begin{array}{l}\text { Mersereau et al. }(2004)^{(9)} \text {; Kelly et al. }(1996)^{(20)} \\
\quad \text { Kaplan et al. }(1988)^{(39)}\end{array}$ \\
\hline $\mathrm{Ml}$ & $2 \cdot 12$ & $2 \cdot 03$ & $1 \cdot 17-3 \cdot 07$ & $1 \cdot 12-2 \cdot 94$ & $\begin{array}{l}\text { Abby et al. }(1998)^{(40)} \text {; Arias }(2004)^{(41)} \text {; Thom } \\
\text { et al. }(2006)^{(42)} \text {; Cohen et al. }(2001)^{(43)} ; \text { Nease Jr } \\
\left.\text { et al. }(1995)^{(44)} \text {; Kuntz et al. (1999) }\right)^{(45)}\end{array}$ \\
\hline $\begin{array}{l}\mathrm{CC} \\
\mathrm{B}_{12}\end{array}$ & \multicolumn{2}{|c|}{$0 \cdot 31$} & \multicolumn{2}{|c|}{$0.17-0.45$} & $\begin{array}{l}\text { Arias }(2004)^{(41)} ; \text { Ness et al. }(1999)^{(46)} \\
\text { Kelly et al. }(1996)^{(20)} ; \text { Kaplan et al. }(1988)^{(39)}\end{array}$ \\
\hline \multicolumn{6}{|c|}{ Costs (thousands of dollars) } \\
\hline $\begin{array}{l}\text { NTD } \\
\text { MI }\end{array}$ & $\$ 32 \cdot \overline{6}$ & $\begin{array}{r}\$ 185 \cdot 5 \\
\$ 32 \cdot 7\end{array}$ & - & $\begin{array}{l}\$ 5 \cdot 0-\$ 185 \cdot 5 \\
2 \cdot 7\end{array}$ & $\begin{array}{l}\text { Mersereau et al. }(2004)^{(9)} \text {; Grosse et al. }(2005)^{(21)} \\
\text { Thom et al. }(2006)^{(42)} \text {; Cohen et al. }(2001)^{(43)} \\
\text { Kuntz et al. }(1999)^{(45)} \text {; Wong et al. }(1990)^{(47)} \text {; } \\
\text { Stinnett et al. (1996) }\end{array}$ \\
\hline $\mathrm{CC}$ & \multicolumn{2}{|c|}{$\$ 31 \cdot 8$} & \multicolumn{2}{|c|}{$\$ 5 \cdot 0-\$ 31 \cdot 8$} & $\begin{array}{l}\text { Frazier et al. }(2000)^{(49)} \text {; Khandker et al. }(2000)^{(50)} \text {; } \\
\quad \text { Loeve et al. }(2000)^{(51)} ; \text { Ness et al. }(2000)^{(52)} ; \\
\text { Pignone et al. }(2005)^{(53)} \text {; Pignone et al. }(2002)^{(54)} \text {; } \\
\text { Vijan et al. }(2001)^{(55)} \text {; Wagner et al. }(1996)^{(56)}\end{array}$ \\
\hline $\mathrm{B}_{12}$ & \multicolumn{2}{|c|}{$\$ 5 \cdot 3$} & \multicolumn{2}{|c|}{$\$ 5 \cdot 0-\$ 50 \cdot 0$} & Kelly et al. $(1996)^{(20)}$ \\
\hline
\end{tabular}

QALY, quality-adjusted life years; NTD, neural tube defects; MI, myocardial infarctions; CC, colon cancer; $B_{12}$, vitamin $B_{12}$ masking.

${ }^{*}$ Assuming a $3 \%$ discount rate.

acid costs, adjusted for cost declines since $1996^{(20,21)}$. The fortification costs were doubled in sensitivity analysis.

\section{Results}

\section{Incidence}

Figure 2 shows the projected per cent decline in annual disease incidence for NTD, MI and colon cancer, comparing the post-fortification scenarios with pre-fortification.

For NTD-affected pregnancies, average annual incidence for all racial/ethnic groups was predicted to decrease by $5 \%, 24 \%$ and $39 \%$ for the 140,350 and $700 \mu \mathrm{g} / 100 \mathrm{~g}$ fortification scenarios, respectively. Mexican-Americans were consistently projected to have the largest per cent declines and blacks the lowest. Average annual MI incidence was predicted to decrease by $2 \%, 8 \%$ and $14 \%$ for the lowestto-highest post-fortification levels, while projected declines of colon cancer were $2 \%, 11 \%$ and $15 \%$. The racial/ethnic subgroups with the greatest predicted benefit were those with the largest post-fortification increases in per cent reaching the risk-reduction folate intake thresholds for each disease outcome. Among older females, for example, whites were estimated to experience the largest increases in per cent consuming greater than $400 \mu \mathrm{g}$ total folate/d, and were predicted to experience the greatest declines in disease incidence. On the other hand, older black females were predicted to experience a $0-1 \%$ increase in $\mathrm{MI}$ incidence, due to a decrease in the proportion consuming more than $400 \mu \mathrm{g} / \mathrm{d}$.

Table 3 shows the projected total annual number of events averted, QALY gained and costs incurred for the 


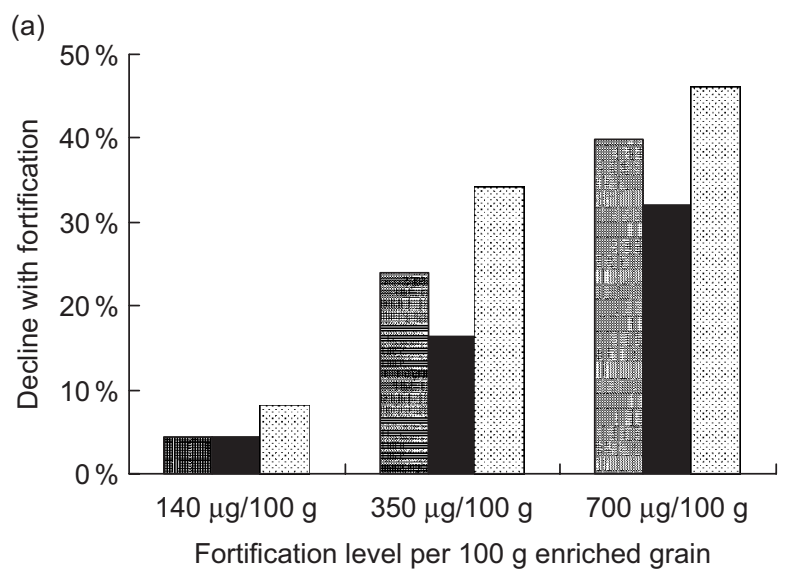

(b)
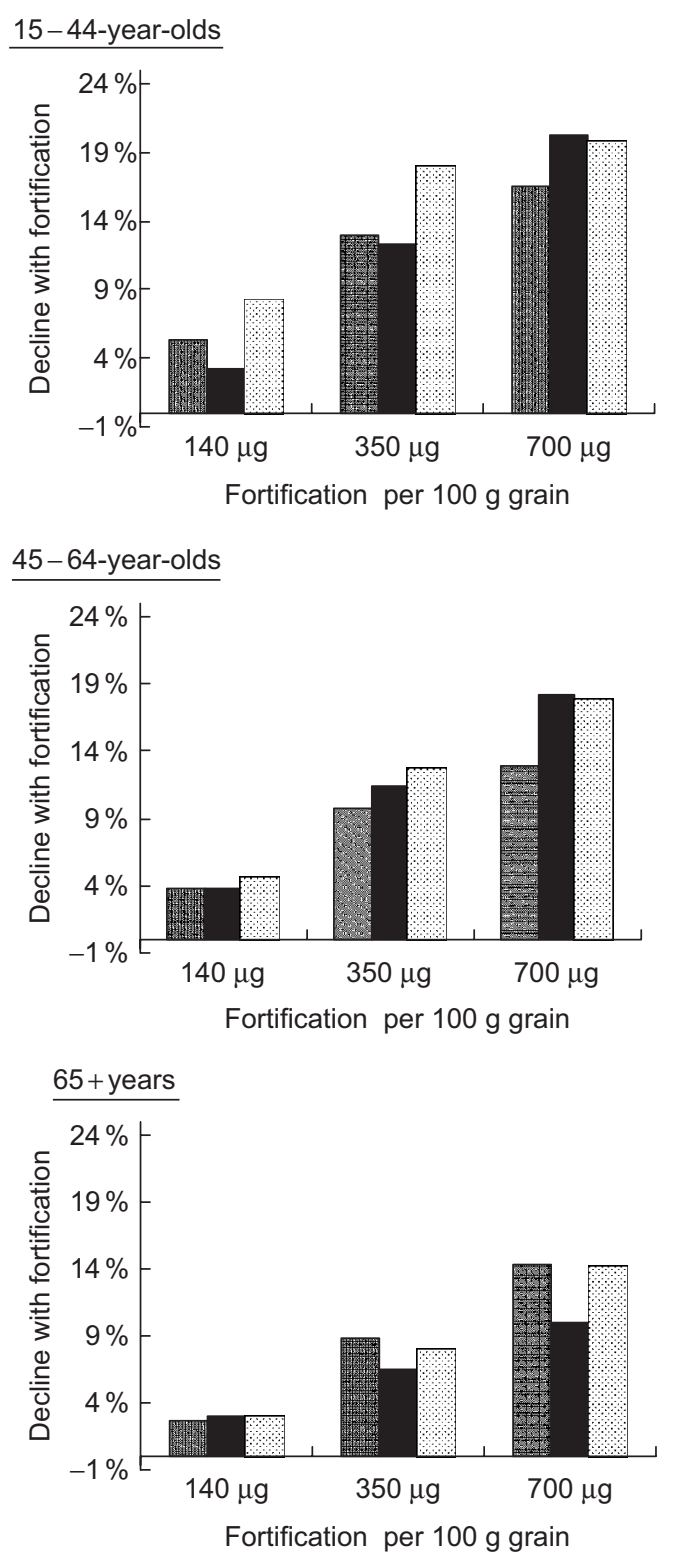

$\underline{\text { Female }}$
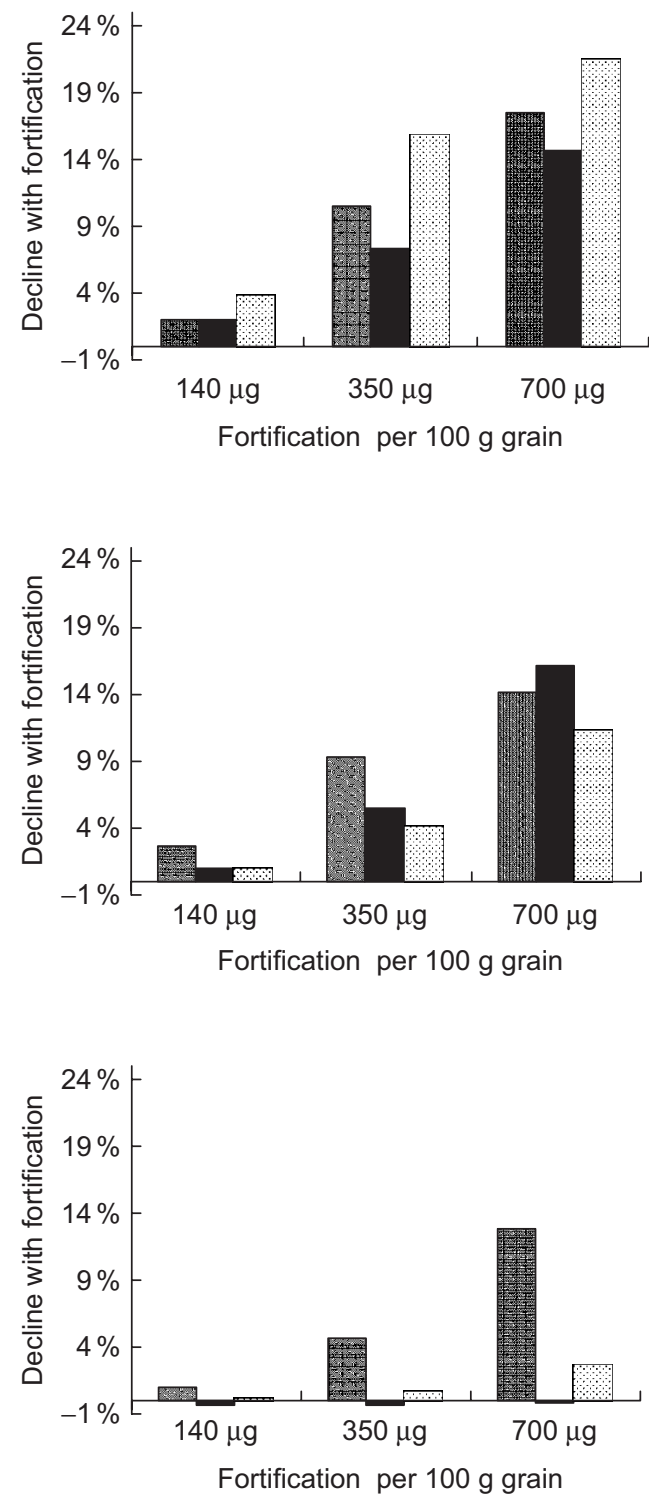

Fig. 2 (a) Per cent decline in annual incidence of neural tube defects, (b) myocardial infarctions and (c) colon cancers, after folic acid fortification, by age, gender, race/ethnicity and fortification strategy ( $\square$, white; $\mathbf{\square}$, black; $\square$, Mexican-American) 
(c)

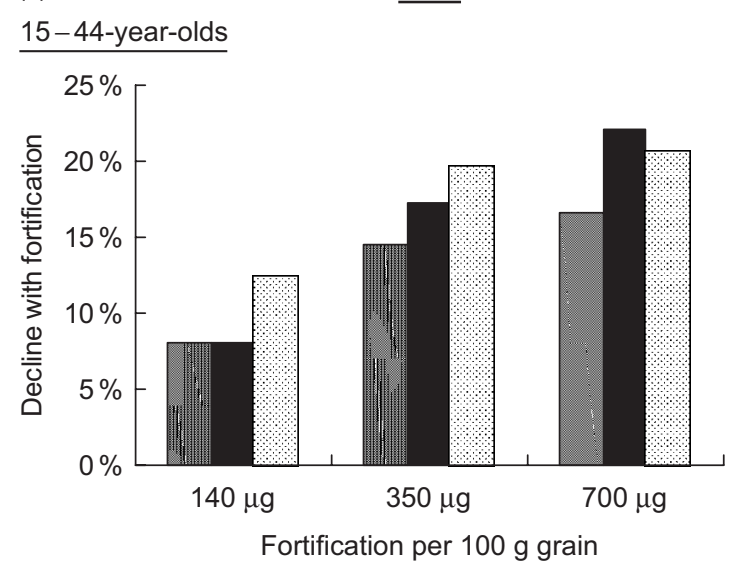

45-64-year-olds
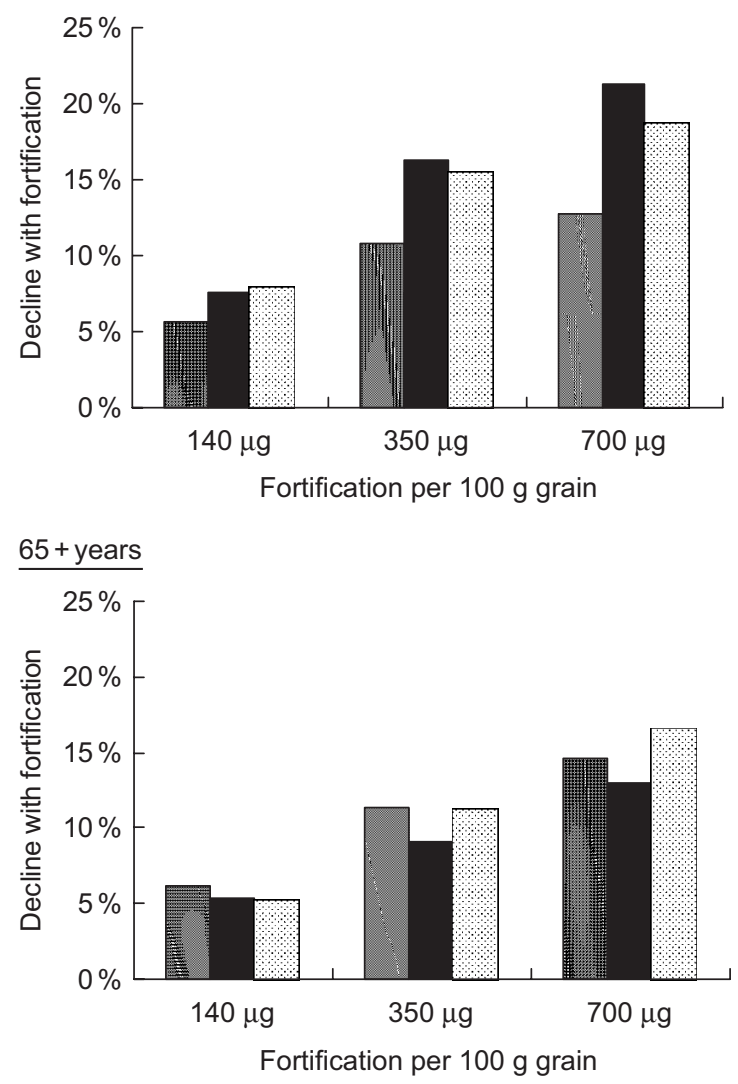

Fig. 2 Continued

US population. The model predicted that the greatest benefits would be in MI prevention, with 16862 cases averted per year at the $140 \mu \mathrm{g}$ fortification level and 88172 at the highest fortification level. Between 6261 and 38805 annual cases of colon cancer and 182 and 1423 annual NTD would be prevented, while 15-820 new annual cases of $\mathrm{B}_{12}$ masking would be caused.

\section{Quality-of-life and cost measures}

Fortification was predicted to be cost-saving and to provide positive net QALY gains at all fortification levels, and
Female
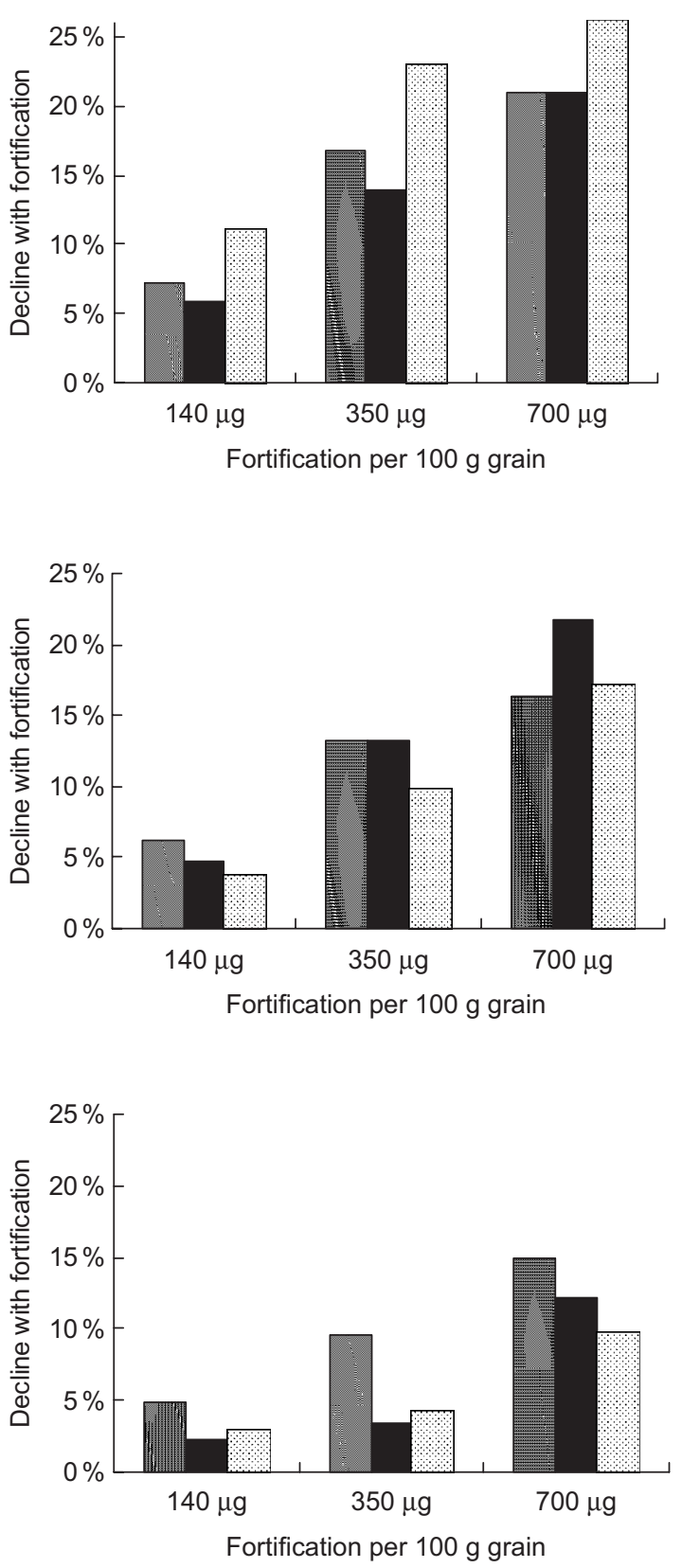

the $700 \mu \mathrm{g} / 100 \mathrm{~g}$ strategy was projected to have the largest health gain and cost savings, with over 320000 QALY gained and over $\$ 4$ billion saved per year (Table 3). The predicted annual gains of over 26000 QALY and savings of over \$263 million from NTD prevention alone far outweighed the QALY lost and costs incurred from $\mathrm{B}_{12}$ masking and fortification itself, which combined were predicted to result in annual losses of fewer than 260 QALY and \$15 million even at the highest fortification level. QALY gains and cost savings due to MI and colon cancers averted each year would be even greater, with MI 
Table 3 Annual QALY and costs associated with US folic acid fortification, by fortification strategy and outcome

\begin{tabular}{|c|c|c|c|c|c|c|}
\hline Strategy* & NTD & MI & $\mathrm{CC}$ & $\mathrm{B}_{12}$ & \multicolumn{2}{|c|}{ Net } \\
\hline \multicolumn{7}{|l|}{ Events averted } \\
\hline $140 \mu \mathrm{g} / 100 \mathrm{~g}$ & 182 & 16862 & 6261 & -15 & \multicolumn{2}{|c|}{23289} \\
\hline $350 \mu \mathrm{g} / 100 \mathrm{~g}$ & 883 & 53011 & 20110 & -184 & \multicolumn{2}{|c|}{73821} \\
\hline $700 \mu \mathrm{g} / 100 \mathrm{~g}$ & 1423 & 88172 & 38805 & -820 & \multicolumn{2}{|c|}{127579} \\
\hline \multicolumn{7}{|l|}{ QALY gained } \\
\hline $140 \mu \mathrm{g} / 100 \mathrm{~g}$ & 3436 & 35458 & 17402 & -5 & \multicolumn{2}{|c|}{56291} \\
\hline $350 \mu \mathrm{g} / 100 \mathrm{~g}$ & 16697 & 111121 & 57403 & -57 & \multicolumn{2}{|c|}{185165} \\
\hline $700 \mu \mathrm{g} / 100 \mathrm{~g}$ & 26899 & 184149 & 112146 & -254 & \multicolumn{2}{|c|}{322940} \\
\hline \multicolumn{5}{|c|}{ Costs incurred (millions of dollars) $\dagger$} & Fortification costs & Net costs \\
\hline $140 \mu \mathrm{g} / 100 \mathrm{~g}$ & $-\$ 33 \cdot 7$ & $-\$ 550 \cdot 8$ & $-\$ 199 \cdot 4$ & $\$ 0 \cdot 1$ & $\$ 3 \cdot 3$ & $-\$ 780 \cdot 5$ \\
\hline $350 \mu \mathrm{g} / 100 \mathrm{~g}$ & $-\$ 163 \cdot 8$ & $-\$ 1731 \cdot 5$ & $-\$ 640 \cdot 4$ & $\$ 1 \cdot 0$ & $\$ 6 \cdot 0$ & $-\$ 2528 \cdot \varepsilon$ \\
\hline $700 \mu \mathrm{g} / 100 \mathrm{~g}$ & $-\$ 263.9$ & $-\$ 2880 \cdot 0$ & $-\$ 1235 \cdot 7$ & $\$ 4 \cdot 3$ & $\$ 10 \cdot 5$ & $-\$ 4364 \cdot \varepsilon$ \\
\hline
\end{tabular}

QALY, quality-adjusted life years; NTD, neural tube defects; MI, myocardial infarctions; CC, colon cancer; $B_{12}$, vitamin $B_{12}$ masking. * Strategies labelled by amount of fortification in $\mu \mathrm{g}$ of folic acid added per $100 \mathrm{~g}$ of enriched grain product.

tDisease-specific costs do not include fortification costs.

Table 4 Annual QALY and costs (millions of dollars) associated with US folic acid fortification, by gender, age and race/ethnicity

\begin{tabular}{|c|c|c|c|c|c|c|}
\hline \multirow[b]{2}{*}{ Strategy* } & \multicolumn{2}{|c|}{ Non-Hispanic white } & \multicolumn{2}{|c|}{ Non-Hispanic black } & \multicolumn{2}{|c|}{ Mexican-American } \\
\hline & QALY & Costs & QALY & Costs & QALY & Costs \\
\hline \multicolumn{7}{|c|}{ Men aged $15-44$ years } \\
\hline $140 \mu \mathrm{g} / 100 \mathrm{~g}$ & 3041 & $-\$ 45 \cdot 23$ & 506 & $-\$ 7 \cdot 50$ & 265 & $-\$ 3 \cdot 86$ \\
\hline $350 \mu \mathrm{g} / 100 \mathrm{~g}$ & 7241 & $-\$ 108 \cdot 51$ & 1849 & $-\$ 27 \cdot 84$ & 551 & $-\$ 8 \cdot 11$ \\
\hline $700 \mu \mathrm{g} / 100 \mathrm{~g}$ & 9078 & $-\$ 135 \cdot 52$ & 2996 & $-\$ 45 \cdot 19$ & 600 & $-\$ 8 \cdot 72$ \\
\hline \multicolumn{7}{|c|}{ Men aged $45-64$ years } \\
\hline $140 \mu \mathrm{g} / 100 \mathrm{~g}$ & 12939 & $-\$ 194 \cdot 42$ & 2336 & $-\$ 35 \cdot 05$ & 642 & $-\$ 9 \cdot 65$ \\
\hline $350 \mu \mathrm{g} / 100 \mathrm{~g}$ & 31967 & $-\$ 482 \cdot 75$ & 6846 & $-\$ 103 \cdot 34$ & 1700 & $-\$ 25 \cdot 68$ \\
\hline $700 \mu \mathrm{g} / 100 \mathrm{~g}$ & 41703 & $-\$ 630 \cdot 77$ & 10745 & $-\$ 162 \cdot 67$ & 2358 & $-\$ 35 \cdot 68$ \\
\hline \multicolumn{7}{|c|}{ Men aged $65+$ years } \\
\hline $140 \mu \mathrm{g} / 100 \mathrm{~g}$ & 13204 & $-\$ 190 \cdot 82$ & 1663 & $-\$ 24 \cdot 61$ & 334 & $-\$ 4.94$ \\
\hline $350 \mu \mathrm{g} / 100 \mathrm{~g}$ & 38477 & $-\$ 569 \cdot 02$ & 3394 & $-\$ 50 \cdot 56$ & 860 & $-\$ 12 \cdot 79$ \\
\hline $700 \mu \mathrm{g} / 100 \mathrm{~g}$ & 59677 & $-\$ 888.08$ & 5129 & $-\$ 76 \cdot 52$ & 1483 & $-\$ 22 \cdot 15$ \\
\hline \multicolumn{7}{|c|}{ Women aged $15-44$ years } \\
\hline $140 \mu \mathrm{g} / 100 \mathrm{~g}$ & 2627 & $-\$ 27 \cdot 21$ & 532 & $-\$ 6 \cdot 18$ & 1068 & $-\$ 10 \cdot 17$ \\
\hline $350 \mu \mathrm{g} / 100 \mathrm{~g}$ & 13404 & $-\$ 141 \cdot 13$ & 1923 & $-\$ 22 \cdot 68$ & 4426 & $-\$ 43 \cdot 23$ \\
\hline $700 \mu \mathrm{g} / 100 \mathrm{~g}$ & 22210 & $-\$ 233 \cdot 64$ & 3722 & $-\$ 43.99$ & 5964 & $-\$ 57 \cdot 89$ \\
\hline \multicolumn{7}{|c|}{ Women aged $45-64$ years } \\
\hline $140 \mu \mathrm{g} / 100 \mathrm{~g}$ & 5335 & $-\$ 78 \cdot 24$ & 802 & $-\$ 11 \cdot 60$ & 113 & $-\$ 1 \cdot 61$ \\
\hline $350 \mu \mathrm{g} / 100 \mathrm{~g}$ & 16605 & $-\$ 251 \cdot 04$ & 3998 & $-\$ 60 \cdot 75$ & 412 & $-\$ 6 \cdot 10$ \\
\hline $700 \mu \mathrm{g} / 100 \mathrm{~g}$ & 24415 & $-\$ 372 \cdot 64$ & 10916 & $-\$ 169 \cdot 90$ & 1017 & $-\$ 15 \cdot 45$ \\
\hline \multicolumn{7}{|c|}{ Women aged $65+$ years } \\
\hline $140 \mu \mathrm{g} / 100 \mathrm{~g}$ & 6295 & $-\$ 79 \cdot 78$ & 87 & $-\$ 0 \cdot 38$ & 48 & $-\$ 0.58$ \\
\hline $350 \mu \mathrm{g} / 100 \mathrm{~g}$ & 18833 & $-\$ 262 \cdot 02$ & 192 & $-\$ 1 \cdot 52$ & 95 & $-\$ 1 \cdot 26$ \\
\hline $700 \mu \mathrm{g} / 100 \mathrm{~g}$ & 42384 & $-\$ 618.09$ & 924 & $-\$ 9 \cdot 45$ & 279 & $-\$ 3 \cdot 86$ \\
\hline
\end{tabular}

QALY, quality-adjusted life years.

* Strategies labelled by amount of fortification in $\mu \mathrm{g}$ of folic acid added per $100 \mathrm{~g}$ of enriched grain product.

prevention alone predicted to save 184000 QALY and \$3 billion annually at the $700 \mu \mathrm{g}$ level.

The model predicted the $700 \mu \mathrm{g}$ fortification level to yield the greatest net QALY gains and cost savings for all age, gender and racial/ethnic subgroups (Table 4). Benefits were projected to increase with age, with males predicted to benefit more than females in most populations. At all fortification levels, the highest gains were expected in white males aged 65 years and older, with predicted annual gains of over 13000 QALY and $\$ 190$ million at the currently enacted level and over 59000 QALY and $\$ 888$ million at the $700 \mu \mathrm{g}$ level. Among racial/ ethnic categories, whites were projected to experience the greatest gains and Mexican-Americans the fewest.

\section{Sensitivity analyses}

This analysis projected substantial fortification benefits despite predicting at the currently enacted fortification level a $5 \%$ reduction in NTD rates, which is far less than the 20-30\% declines estimated from observed data $^{(6,8,9,17)}$. Due to lack of adequate dose-response data, the model allows only for reduced NTD risk at folate consumption of $>400 \mu \mathrm{g} / \mathrm{d}$, yet there may be benefits in NTD risk-reduction at lower levels.

To evaluate the effect of this possibility, three additional NTD dose-response assumptions were tested (Fig. 3a), allowing women to benefit from folate intake over $200 \mu \mathrm{g} / \mathrm{d}^{(57-60)}$. Curve A assumes a dose-response gradient similar to that of colon cancer - albeit through different 
mechanisms - while $\mathrm{B}$ and $\mathrm{C}$ were calculated by decreasing the risk ratios of function $\mathrm{A}$ by $25 \%$ and $50 \%$, respectively. All three functions maintained the base-case assumption of a $50 \%$ reduced risk for intake $>400 \mu \mathrm{g} / \mathrm{d}$ compared with $\leq 400 \mu \mathrm{g} / \mathrm{d}$. Given the use of a similar $400 \mu \mathrm{g} / \mathrm{d}$ threshold for reducing the risk of MI by folate intake and evidence of potential benefit at lower levels without a threshold effect $^{(61)}$, an analogous sensitivity analysis on this doseresponse function was performed (Fig. 3b).

When risk reduction benefits for NTD and MI were allowed at lower folate intakes, the model predicted that
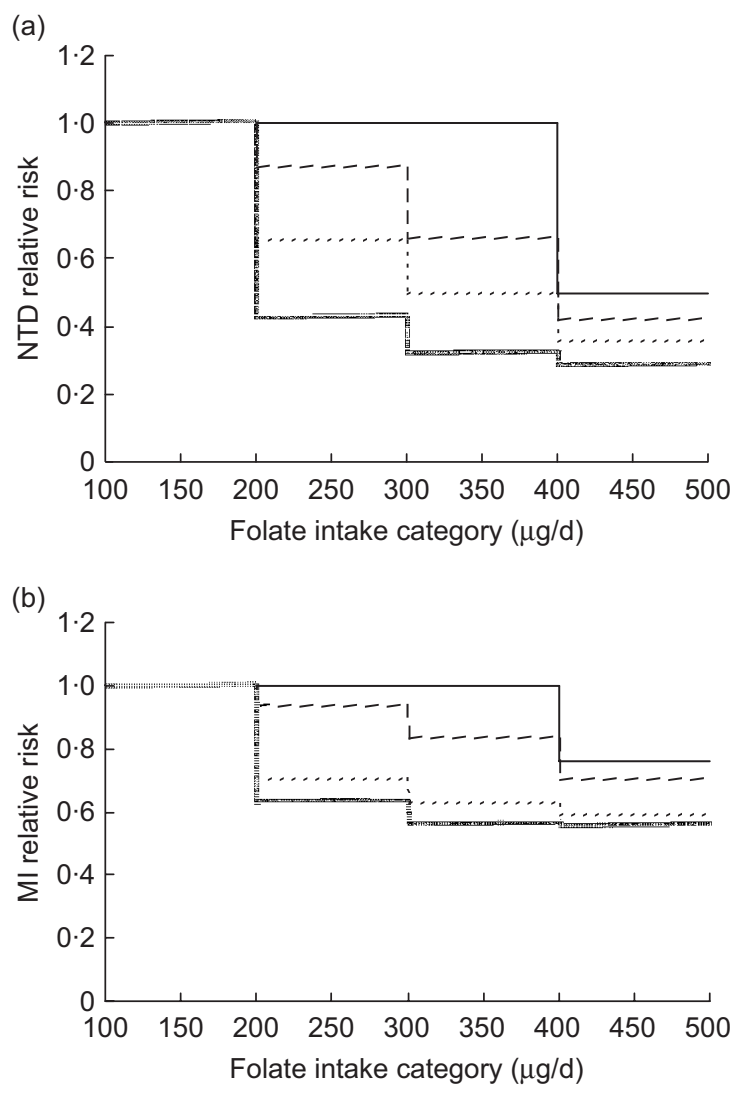

Fig. 3 Dose-response assumptions used in sensitivity analyses for (a) neural tube defects (NTD) and (b) myocardial infarctions (MI). Risk is relative to an average folate intake of $<200 \mu \mathrm{g}$ per day ( - , base case; ...., A; ....., B; more events would be prevented and there would be greater reductions in disease incidence. The use of NTD function B predicted at the $140 \mu \mathrm{g}$ level a $23 \%$ risk reduction, the closest approximation to observed data. When applying these functions for both NTD and MI dose-response, the $700 \mu \mathrm{g}$ strategy was predicted to save 370000 QALY and \$5 billion, compared with 320000 QALY and $\$ 4$ billion in the base case (Table 5).

To evaluate the effect of the model's other assumptions, a range of estimates were applied for QALY and costs (Table 2), relative risk of NTD-affected pregnancy (10\% and $90 \%$ ), masking risk (30-200\% of base case), female PA risk $(150 \% \text { of base case })^{(34,35,62)}$, and discount rate $(0 \%$ and $5 \%)$. Even with extreme estimates that would bias results away from fortification, none of these variations - applied individually or concurrently - changed the rankings between strategies or the conclusion that QALY gains and cost savings would result from fortification up to the highest level considered. When biasing against fortification overall, the conclusions remained the same, even though the predicted QALY gained and costs saved were smaller: for all subgroups, fortification would remain cost saving, and the $700 \mu \mathrm{g}$ strategy would provide the greatest total QALY gains, with \$486 million saved and over 196000 QALY gained.

\section{Discussion}

It was predicted for three post-fortification strategies that the projected health and economic benefits gained from preventing NTD, MI and colon cancers in the US population far exceeded those lost due to fortification itself and increased $\mathrm{B}_{12}$ masking risk, with significant variations by age, gender and race/ethnicity. For all health outcomes, the QALY and cost benefits to whites were projected to be significantly greater than those to blacks and MexicanAmericans. With predicted population benefits of 322940 QALY gained and $\$ 4.4$ billion saved, fortifying at $700 \mu \mathrm{g} /$ $100 \mathrm{~g}$ enriched grain product - the highest level considered in this analysis - strongly dominated all other scenarios. The benefits of higher fortification levels were predicted to far outweigh the associated risks for all populations, and in all sensitivity analyses.

Table 5 QALY and costs (millions of dollars) associated with folic acid fortification, using alternative NTD and MI dose-response functions*

\begin{tabular}{|c|c|c|c|c|c|c|}
\hline \multirow[b]{2}{*}{ Strategy† } & \multicolumn{5}{|c|}{ Annual QALY gains } & \multirow[b]{2}{*}{ Annual net costs } \\
\hline & NTD & MI & $\mathrm{CC}$ & $\mathrm{B}_{12}$ & Net QALY gain & \\
\hline No fortification & 0 & 0 & 0 & 0 & 0 & $\$ 0$ \\
\hline $140 \mu \mathrm{g} / 100 \mathrm{~g}$ & 15842 & 114532 & 17402 & -5 & 147770 & $-\$ 2154$ \\
\hline $350 \mu \mathrm{g} / 100 \mathrm{~g}$ & 28445 & 193475 & 57403 & -57 & 279267 & $-\$ 3958$ \\
\hline $700 \mu \mathrm{g} / 100 \mathrm{~g}$ & 33268 & 224325 & 112146 & -254 & 369485 & $-\$ 5078$ \\
\hline
\end{tabular}

QALY, quality-adjusted life years; NTD, neural tube defects; MI, myocardial infarctions; CC, colon cancer; $B_{12}$, vitamin $B_{12}$ masking.

${ }^{*}$ NTD dose-response function assumes the following relative risks of NTD-affected pregnancy: $0 \cdot 36 ; 0.50$ and 0.65 for maternal folate intake of $>400,301-400$ and $201-300 \mu \mathrm{g} / \mathrm{d}$, respectively, compared to $\leq 200 \mu \mathrm{g} / \mathrm{d}$. Ml dose-response function assumes the following relative risks of $\mathrm{Ml}: 0.59 ; 0.63$ and 0.70 for folate intake of $>400,301-400$ and $201-300 \mu \mathrm{g} / \mathrm{d}$, respectively, compared to $\leq 200 \mu \mathrm{g} / \mathrm{d}$.

tStrategies labelled by amount of fortification in $\mu \mathrm{g}$ of folic acid added per $100 \mathrm{~g}$ of enriched grain product. 
The substantial racial/ethnic differences predicted in disease outcomes were caused primarily by differences in total folate intake. Although disease incidence was not projected to decrease among all populations, this effect was caused by the unrealistic discontinuous risk functions used to avoid interpolating the epidemiological data analysed in risk strata. Targeted supplement-use interventions may be necessary to further mitigate disparities and reduce disease prevalence, and future research should aim to identify racial/ethnic differences in intake of fortified and non-fortified foods.

The results of the present analysis provide evidence for recommending that fortification be increased to at least $700 \mu \mathrm{g}$ of folic acid per $100 \mathrm{~g}$ of enriched grain product, corroborating prior research that predicted greater economic gains at higher fortification levels ${ }^{(20)}$. The analysis demonstrates that the benefits of higher fortification would exceed the risks even in the most unfavourable subgroups. It also addresses other important considerations by using estimates of folate intake that are national, subgroup-specific, and corrected for the bias caused by the use of $1 \mathrm{~d}$ dietary intake data.

There are several limitations to consider when interpreting these results. The use of limited data on the dose-response relationships between folate intake and disease risk may have underestimated the post-fortification health benefits. However, even when using more realistically continuous - albeit uncertain - doseresponse assumptions for both NTD and MI, the conclusions of positive benefit-risk trade-offs for all subgroups and of greater benefit at higher fortification levels - did not change, and the model predicted that more NTD and MI would be prevented and that the NTD reduction would be consistent with that observed post-policy ${ }^{(6,8,9,17)}$.

A related source of uncertainty is that synthetic folic acid is more bioavailable to absorption by the human body than is naturally occurring folate. While this factor can be incorporated using dietary folate equivalents (DFE) - a measure that adjusts intake estimates for these absorption differences - we were unable to include DFE in our analysis due to data limitations. With fortification resulting in greater proportions of intake from synthetic folic acid, the model's use of total folate may thus have caused the benefits of fortification to be underestimated, and the risks to be overestimated. Conversely, because this factor was not considered in estimating folate-specific risks of MI and colon cancer, the benefits for dietary sources of folate may be overstated. The model's projected cost savings associated with fortification may have been underestimated, as lifetime caregiving costs of NTDaffected individuals were not included, reduced costs associated with the proportion of NTD ending in a terminated pregnancy were excluded, and MI costs were used that may not consider the increased costs of today's standards of care. By the same token, we may have overestimated QALY losses due to MI because survival has been improved by today's standards of care. Taken as a whole, it is unlikely that any such positive or negative effects would substantially impact the results of the analysis, or alter the conclusions of overall benefit.

Given the suggestion of possible insignificant or even adverse effects of increased folate intake on MI risk and on colorectal cancer progression among individuals with pre-existing disease ${ }^{(3,63-67)}$, the benefits to MI as well as to colon cancer could be less than predicted by our model. However, recent evidence also indicates a positive folatestroke association ${ }^{(68-70)}$ and an overall cardiovascular benefit ${ }^{(16)}$, and our results may thus underestimate benefits. The potential risk to colorectal cancer progression may appear to be supported by recent published research indicating a possible temporary delay in the ongoing decline in colorectal cancer incidence ${ }^{(71)}$, but this could be in part an artefact of increased use of colonoscopy. In addition, a recent report from the National Cancer Institute indicates that not only is incidence still decreasing at $2 \%$ per year, but also mortality - which one would expect to increase if fortification were accelerating growth of existing tumours - is also declining at an annual rate of close to $4 \%{ }^{(72)}$. This analysis is thus important for motivating further trials among people without existing disease, while simultaneously suggesting caution among policymakers who may be considering potential fortification increases.

By not formally allowing competing risks between disease outcomes while allocating benefit for each disease event averted, the model may have double-counted some of the benefits gained because multiple events may be occurring per individual. The analysis did not incorporate potential associations of folic acid intake with increased twinning ${ }^{(73-76)}$, with other cancers ${ }^{(77-79)}$, or with cognitive decline ${ }^{(80)}$. Given the lack of consistent evidence for such outcomes, it is unclear in which direction their inclusion may impact results, yet the strength of the findings from our analysis suggests that the conclusion of overall benefit associated with increased folate intake would not be changed.

While these benefit-risk estimates assume a steady state, in reality fortification's effect on NTD and $B_{12}$ maskings would be relatively immediate, while that for MI and colon cancer could take up to $5^{(36)}$ and 15 years $^{(37)}$, respectively. However, not only were fortification's benefits for NTD alone predicted to outweigh the potential $\mathrm{B}_{12}$ masking risk, this risk may in fact have been overestimated given our use of a conservative risk threshold of $1000 \mu \mathrm{g} / \mathrm{d}$ despite no evidence of harm below $5000 \mu \mathrm{g} / \mathrm{d}^{(10)}$. It is also important to note that while there is conflicting evidence regarding whether masking has increased since fortification ${ }^{(81-83)}$, current medical knowledge regarding appropriate screening measures for $\mathrm{B}_{12}$ deficiency suggests that the fear of delayed diagnosis by physicians may not in fact be realised. The risk, however, may be that symptom improvement due to 
masking could reduce patients' likelihood of seeking medical advice until after neurological complications have occurred ${ }^{(84)}$. Nevertheless, with the low prevalence of potential masking - estimated at $0.09 \%$ in older women before fortification and $0.61 \%$ after $^{(83)}$ - even with conservative estimates our model predicted that this risk would be outweighed by the benefits.

Given the uncertainty involved, future research should clarify the dose-response relationships and benefit-risk associations between folate intake and disease risk. This is especially important for outcomes such as MI, colon cancer, stroke, cognitive decline and $\mathrm{B}_{12}$ masking, for which causality has not yet been established; there has been conflicting evidence on potential risks, in particular among individuals with pre-existing disease; or there remains debate over the validity of the evidence ${ }^{(3,16,67-70,81-88)}$. In addition, future policy decisions may consider $\mathrm{B}_{12} \mathrm{CO}-$ fortification or a more stringent screen for $\mathrm{B}_{12}$ deficiency to offset the potentially elevated $\mathrm{B}_{12}$ masking risks due to higher fortification, and may evaluate a broader range of fortification levels to better determine the optimal fortification strategy.

In summary, folic acid fortification was implemented in the USA in 1998 to reduce the chance of NTD in newborns. While there are potential risks of increased folate intake to populations with vitamin $\mathrm{B}_{12}$ deficiency, there may also be benefits in preventing MI and colon cancer. Overall, in considering the benefit-risk trade-offs of folic acid fortification, the present study suggests that the health and economic gains may outweigh the losses for the US population as a whole, and that additional studies on the potential benefits and hazards associated with folate intake - as well as an in-depth evaluation of the level of fortification - deserve further consideration in order to maximise net gains among all racial/ethnic, age and gender-specific subgroups.

\section{Acknowledgements}

Conflict of interest: There are no conflicts of interest.

Funding source: This study was supported by the Dana-Farber/Harvard Cancer Center Program in Cancer Outcomes Research Training, National Cancer Institute training grant \# R25 CA92203, and by CISNET, National Cancer Institute grant \# UOI CA88204. The work of all authors is independent of these funders.

Authorship responsibilities: All authors were involved in the study design and concept. K.M.K. and T.G.K.B. obtained funding. T.G.K.B. acquired all data, drafted the manuscript, and conducted all analyses. K.M.K. supervised study implementation. All authors were involved in interpretation of data and analyses, offered critical revisions to the manuscript, and approved the final version. T.G.K.B. is the guarantor. Ethical approval was not required for this analysis.

\section{References}

1. Czeizel AE \& Dudas I (1992) Prevention of the first occurrence of neural-tube defects by periconceptional vitamin supplementation. $N$ Engl J Med 327, 1832-1835.

2. MRC Vitamin Study Research Group (1991) Prevention of neural tube defects: results of the Medical Research Council Vitamin Study. Lancet 338, 131-137.

3. Bazzano LA, Reynolds K, Holder KN \& He J (2006) Effect of folic acid supplementation on risk of cardiovascular diseases: a meta-analysis of randomized controlled trials. JAMA 296, 2720-2726.

4. Bentley JR, Ferrini RL \& Hill LL (1999) American College of Preventive Medicine public policy statement. Folic acid fortification of grain products in the US to prevent neural tube defects. Am J Prev Med 16, 264-267.

5. Dickinson CJ (1995) Does folic acid harm people with vitamin $\mathrm{B}_{12}$ deficiency? OJM 88, 357-364.

6. Erickson JD (2002) Folic acid and prevention of spina bifida and anencephaphly. MMWR Recomm Rep 51, 1-3.

7. Koehler KM, Pareo-Tubbeh SL, Romero LJ, Baumgartner RN \& Garry PJ (1997) Folate nutrition and older adults: challenges and opportunities. J Am Diet Assoc 97, $167-173$.

8. Mathews TJ, Honein MA \& Erickson JD (2002) Spina bifida and anencephaly prevalence - United States, 1991-2001. MMWR Recomm Rep 51, 9-11.

9. Centers for Disease Control and Prevention (CDC) (2004) Spina bifida and anencephaly before and after folic acid mandate - United States, 1995-1996 and 1999-2000. MMWR Morb Mortal Wkly Rep 53, 362-365.

10. National Academy of Sciences, Institute of Medicine, Food and Nutrition Board (1998) Dietary Reference Intakes: Thiamin, Riboflavin, Niacin, Vitamin $B_{6}$, Folate, Vitamin $B_{12}$, Pantothenic acid, Biotin, and Choline. Washington, DC: National Academy Press.

11. National Institutes of Health Clinical Nutrition Service (2001) Facts about dietary supplements: folate. http://ods. od.nih.gov/factsheets/cc/folate.html (accessed November 2004).

12. Tucker KL, Mahnken B, Wilson PW, Jacques P \& Selhub J (1996) Folic acid fortification of the food supply. Potential benefits and risks for the elderly population [comment]. JAMA 276, 1879-1885.

13. US Food and Drug Administration (1993) Food standards: amendment of standards of identity for enriched grain products to require addition of folic acid. Fed Regist $\mathbf{5 8}$, 53305-53312.

14. US Food and Drug Administration (1996) Food standards: amendment of standards of identity for enriched grain products to require addition of folic acid. Fed Regist $\mathbf{6 1}$, 8781-8797.

15. US Food and Drug Administration (1996) Folic acid fortification fact sheet. http://vm.dfsan.fda.gov/ dms/ wh-folic.html (accessed April 2003).

16. Wald DS, Wald NJ, Morris JK \& Law M (2006) Folic acid, homocysteine, and cardiovascular disease: judging causality in the face of inconclusive trial evidence. BMJ 333, 1114-1117.

17. Williams LJ, Mai CT, Edmonds LD, Shaw GM, Kirby RS, Hobbs CA, Sever LE, Miller LA, Meaney FJ \& Levitt M (2002) Prevalence of spina bifida and anencephaly during the transition to mandatory folic acid fortification in the United States. Teratology 66, 33-39.

18. Tice JA, Ross E, Coxson PG, Rosenberg I, Weinstein MC, Hunink MG, Goldman PA, Williams L \& Goldman L (2001) Cost-effectiveness of vitamin therapy to lower plasma homocysteine levels for the prevention of coronary heart disease: effect of grain fortification and beyond. JAMA $\mathbf{2 8 6}$, 936-943. 
19. Romano PS, Waitzman NJ, Scheffler RM \& Pi RD (1995) Folic acid fortification of grain: an economic analysis. $A m J$ Public Health 85, 667-676.

20. Kelly A, Haddix A, Scanlon K, Helmick C \& Mulinare J (1996) Worked example: cost-effectiveness of strategies to prevent neural tube defects. In Cost-effectiveness in Health and Medicine, pp. 313-348 [M Gold, J Siegel, L Russell and M Weinstein, editors]. New York: Oxford University Press.

21. Grosse SD, Waitzman NJ, Romano PS \& Mulinare J (2005) Reevaluating the benefits of folic acid fortification in the United States: economic analysis, regulation, and public health. Am J Public Health 95, 1917-1922.

22. Bentley TGK, Willett WC, Weinstein MC \& Kuntz KM (2006) Population-level changes in folate intake by age, gender, and race/ethnicity after folic acid fortification. Am J Public Health 96, 2040-2047.

23. Centers for Disease Control and Prevention (2000) Folate status in women of childbearing age - United States, 1999. MMWR Morb Mortal Wkly Rep 49, 962-965.

24. Johnston R \& Staples D (1997) Knowledge and use of folic acid by women of childbearing age - United States, 1997. MMWR Recomm Rep 46, 721-723.

25. Centers for Disease Control and Prevention (CDC) (2002) Folate status in women of childbearing age, by race/ ethnicity - United States, 1999-2000. MMWR Morb Mortal Wkly Rep 51, 808-810.

26. Petrini J, Damus K, Johnston R \& Mattison D (1999) Knowledge and use of folic acid by women of childbearing age - United States, 1995 and 1998. MMWR Recomm Rep 48, 325-327.

27. Williams L, Rasmussen SA, Flores A, Kirby R \& Edmonds LD (2005) Decline in the prevalence of spina bifida and anencephaly by race/ethnicity: 1995-2002. Pediatrics 116 , 580-586.

28. Hamilton B, Sutton P \& Ventura S (2003) Revised birth and fertility rates for the 1990s and new rates for Hispanic populations, 2000 and 2001: United States. Natl Vital Stat Rep $\mathbf{5 1 .}$

29. Anderson KM, Odell PM, Wilson PW \& Kannel WB (1991) Cardiovascular disease risk profiles. Am Heart $J$ 121, 293-298.

30. Centers for Disease Control and Prevention (2006) Health data for all ages - adult mortality by cause: US/State, 1999-2002. http://www.cdc.gov/nchs/health_data_for_all_ ages.htm (accessed October 2006).

31. National Cancer Institute, DCCPS, Surveillance Research Program, Cancer Statistics Branch (1999) Surveillance, Epidemiology, and End Results (SEER) Program SEER*Stat Database: Incidence - SEER 11 Regs Public-Use, Aug 1999 Sub for Hispanics (1992-1997). www.seer.cancer.gov (accessed February 2005).

32. Ries LAG, Eisner MP, Kosary CL, Hankey BF, Miller BA, Clegg L \& Edwards BK (editors) (2002) SEER Cancer Statistics Review, 1973-1999. Bethesda, MD: National Cancer Institute; available at http://seer.cancer.gov/csr/ 1973_1999/

33. Ries LAG, Eisner MP, Kosary CL, Hankey BF, Miller BA, Clegg L, Mariotto A, Feuer EJ \& Edwards BK (editors) (2004) SEER Cancer Statistics Review, 1975-2001. Bethesda, MD: National Cancer Institute; available at http://seer.cancer.gov/csr/1975_2001/

34. Borch K \& Liedberg G (1984) Prevalence and incidence of pernicious anemia. An evaluation for gastric screening. Scand J Gastroenterol 19, 154-160.

35. Pedersen AB \& Mosbech J (1969) Morbidity of pernicious anaemia. Incidence, prevalence, and treatment in a Danish county. Acta Med Scand 185, 449-452.

36. Rimm EB, Willett WC, Hu FB, Sampson L, Colditz GA, Manson JE, Hennekens C \& Stampfer MJ (1998) Folate and vitamin $\mathrm{B}_{6}$ from diet and supplements in relation to risk of coronary heart disease among women. JAMA 279, 359-364.

37. Giovannucci E, Stampfer MJ, Colditz GA, Hunter DJ, Fuchs C, Rosner BA, Speizer FE \& Willett WC (1998) Multivitamin use, folate, and colon cancer in women in the Nurses' Health Study. Ann Intern Med 129, 517-524.

38. US Census Bureau, Population Division (2005) Annual Population Estimates. http://www.census.gov/popest/ national/ (accessed July 2005).

39. Kaplan RM \& Anderson JP (1988) A general health policy model: update and applications. Health Serv Res 23, 203-235.

40. Abby SL, Harris IM \& Harris KM (1998) Homocysteine and cardiovascular disease. J Am Board Fam Pract 11, 391-398.

41. Arias E (2004) United States life tables, 2001. Natl Vital Stat Rep $\mathbf{5 2 .}$

42. Thom T, Haase N, Rosamond $\mathrm{W}$ et al. (2006) Heart disease and stroke statistics - 2006 update: a report from the American Heart Association Statistics Committee and Stroke Statistics Subcommittee. Circulation 113, e85-e151.

43. Cohen DJ, Taira DA, Berezin R, Cox DA, Morice MC, Stone GW \& Grines CL (2001) Cost-effectiveness of coronary stenting in acute myocardial infarction: results from the Stent Primary Angioplasty in Myocardial Infarction (StentPAMI) Trial. Circulation 104, 3039-3045.

44. Nease RF Jr, Kneeland T, O'Connor GT, Sumner W, Lumpkins C, Shaw L, Pryor D \& Sox HC (1995) Variation in patient utilities for outcomes of the management of chronic stable angina. Implications for clinical practice guidelines. Ischemic Heart Disease Patient Outcomes Research Team. JAMA 273, 1185-1190.

45. Kuntz KM, Fleischmann KE, Hunink MGM \& Douglas PS (1999) Cost-effectiveness of diagnostic strategies for patients with chest pain. Ann Intern Med 130, 709-718.

46. Ness RM, Holmes AM, Klein R \& Dittus R (1999) Utility valuations for outcome states of colorectal cancer. $A m \mathrm{~J}$ Gastroenterol 94, 1650-1657.

47. Wong JB, Sonnenberg FA, Salem DN \& Pauker SG (1990) Myocardial revascularization for chronic stable angina. Ann Intern Med 113, 852.

48. Stinnett A, Mittleman M, Weinstein M et al. (1996) Appendix C: the cost-effectiveness of dietary and pharmacologic therapy for cholesterol reduction in adults. In CostEffectiveness in Health and Medicine, pp. 349-391 [M Gold, $\mathrm{J}$ Siegel, L Russell and M Weinstein, editors]. New York: Oxford University Press.

49. Frazier AL, Colditz GA, Fuchs CS \& Kuntz KM (2000) Costeffectiveness of screening for colorectal cancer in the general population. JAMA 284, 1954-1961.

50. Khandker RK, Dulski JD, Kilpatrick JB, Ellis RP, Mitchell JB \& Baine WB (2000) A decision model and cost-effectiveness analysis of colorectal cancer screening and surveillance guidelines for average-risk adults. Int J Technol Assess Health Care 16, 799-810.

51. Loeve F, Brown ML, Boer R, van Ballegooijen M, van Oortmarssen GJ \& Habbema JD (2000) Endoscopic colorectal cancer screening: a cost-saving analysis. J Natl Cancer Inst 92, 557-563.

52. Ness RM, Holmes AM, Klein R \& Dittus R (2000) Cost-utility of one-time colonoscopic screening for colorectal cancer at various ages. Am J Gastroenterol 95, 1800-1811.

53. Pignone M, Russell L \& Wagner J (editors) (2005) Economic Models of Colorectal Cancer Screening in Average-risk Adults: Workshop Summary. London: Institute of Medicine, National Academies Press.

54. Pignone M, Saha S, Hoerger T \& Mandelblatt J (2002) Costeffectiveness analyses of colorectal cancer screening: a systematic review for the US Preventive Services Task Force. Ann Intern Med 137, 96-104. 
55. Vijan S, Hwang EW, Hofer TP \& Hayward RA (2001) Which colon cancer screening test? A comparison of costs, effectiveness, and compliance. Am J Med 111, 593-601.

56. Wagner J, Tunis S, Brown M, Ching A \& Almeida R (1996) Cost-effectiveness of colorectal cancer screening in average-risk adults. In Prevention and Early Detection of Colorectal Cancer, pp. 321-356. [G Young, P Rozen and B Levin, editors]. London: Saunders.

57. Werler M, Shapiro S \& Mitchell A (1993) Periconceptional folic acid exposure and risk of occurrent neural tube defects. JAMA 269, 1257-1261.

58. Daly LE, Kirke PN, Molloy A, Weir DG \& Scott JM (1995) Folate levels and neural tube defects. Implications for prevention [comment]. JAMA 274, 1698-1702.

59. Daly S, Mills JL, Molloy AM, Conley M, Lee YJ, Kirke PN, Weir DG \& Scott JM (1997) Minimum effective dose of folic acid for food fortification to prevent neural-tube defects. Lancet 350, 1666-1669.

60. Wald NJ, Law MR, Morris JK \& Wald DS (2001) Quantifying the effect of folic acid. Lancet 358, 2069-2073.

61. Drogan D, Klipstein-Grobusch K, Dierkes J, Weikert C \& Boeing H (2006) Dietary intake of folate equivalents and risk of myocardial infarction in the European Prospective Investigation into Cancer and Nutrition (EPIC)-Potsdam study. Public Health Nutr 9, 465-471.

62. Carmel R (1996) Prevalence of undiagnosed pernicious anemia in the elderly. Arch Intern Med 156, 1097-1100.

63. Novakovic P, Stempak JM, Sohn KJ \& Kim YI (2006) Effects of folate deficiency on gene expression in the apoptosis and cancer pathways in colon cancer cells. Carcinogenesis 27, 916-924.

64. Cole BF, Baron JA, Sandler RS et al.; Polyp Prevention Study Group (2007) Folic acid for the prevention of colorectal adenomas: a randomized clinical trial. JAMA 297, 2351-2359.

65. Van Guelpen B, Hultdin J, Johansson I, Hallmans G, Stenling R, Riboli E, Winkvist A \& Palmqvist R (2006) Low folate levels may protect against colorectal cancer. Gut $\mathbf{5 5}$, 1461-1466.

66. Lonn E, Yusuf S, Arnold MJ et al.; Heart Outcomes Prevention Evaluation (HOPE) 2 Investigators (2006) Homocysteine lowering with folic acid and B vitamins in vascular disease. $N$ Engl J Med 354, 1567-1577.

67. Bonaa KH, Njolstad I, Ueland PM, Schirmer H, Tverdal A, Steigen T, Wang H, Nordrehaug JE, Arnesen E \& Rasmussen K; NORVIT Trial Investigators (2006) Homocysteine lowering and cardiovascular events after acute myocardial infarction. N Engl J Med 354, 1578-1588.

68. Carlsson CM (2007) Lowering homocysteine for stroke prevention. Lancet 369, 1841-1842.

69. Wang X, Qin X, Demirtas H, Li J, Mao G, Huo Y, Sun N, Liu L \& Xu X (2007) Efficacy of folic acid supplementation in stroke prevention: a meta-analysis. Lancet 369, 1876-1882.

70. Toole J, Malinow M, Chambless L, Spence JD, Pettigrew LC, Howard VJ, Sides EG, Wang CH \& Stampfer M (2004) Lowering homocysteine in patients with ischemic stroke to prevent recurrent stroke, myocardial infarction, and death: the Vitamin Intervention for Stroke Prevention (VISP) Randomized Controlled Trial. JAMA 291, $565-575$.

71. Mason JB, Dickstein A, Jacques PF, Haggarty P, Selhub J, Dallal G \& Rosenberg IH (2007) A temporal association between folic acid fortification and an increase in colorectal cancer rates may be illuminating important biological principles: a hypothesis. Cancer Epidemiol Biomarkers Prev 16, 1325-1329.
72. Ries LAG, Melbert D, Krapcho M et al. (editors) (2007) SEER Cancer Statistics Review, 1975-2004. Bethesda, MD: National Cancer Institute; available at http://seer.cancer. gov/csr/1975_2004/

73. Czeizel AE, Metneki J \& Dudas I (1994) The higher rate of multiple births after periconceptional multivitamin supplementation: an analysis of causes. Acta Genet Med Gemellol (Roma) 43, 175-184.

74. Li Z, Gindler J, Wang H, Berry RJ, Li S, Correa A, Zheng JC, Erickson JD \& Wang Y (2003) Folic acid supplements during early pregnancy and likelihood of multiple births: a population-based cohort study. Lancet 361, 380-384.

75. Lawrence JM, Watkins ML, Chiu V, Erickson JD, Petitti DB \& Kim YI (2004) Food fortification with folic acid and rate of multiple births, 1994-2000. Birth Defects Res A Clin Mol Teratol 70, 948-952.

76. Kucik J \& Correa A (2004) Trends in twinning rates in metropolitan Atlanta before and after folic acid fortification. J Reprod Med 49, 707-712.

77. Kim YI (2004) Will mandatory folic acid fortification prevent or promote cancer? Am J Clin Nutr 80, $1123-1128$.

78. Henao O, Piyathilake C, Waterbor J, Funkhouser E, Johanning GL, Heimburger DC \& Partridge EE (2005) Women with polymorphisms of methylenetetrahydrofolate reductase (MTHFR) and methionine synthase (MS) are less likely to have cervical intraepithelial neoplasia (CIN) 2 or 3. Int J Cancer 113, 991-997.

79. Larsson S, Giovannucci E \& Wolk A (2007) Folate and risk of breast cancer: a meta-analysis. J Natl Cancer Inst $\mathbf{9 9}$, 64-76.

80. Durga J, van Boxtel MP, Schouten EG, Kok FJ, Jolles J, Katan MB \& Verhoef P (2007) Effect of 3-year folic acid supplementation on cognitive function in older adults in the FACIT trial: a randomised, double blind, controlled trial. Lancet 369, 208-216.

81. Mills JL, Von Kohorn I, Conley MR, Zeller JA, Cox C, Williamson RE \& Dufour DR (2003) Low vitamin B-12 concentrations in patients without anemia: the effect of folic acid fortification of grain. Am J Clin Nutr 77, $1474-1477$.

82. Morris MS, Jacques PF, Rosenberg IH \& Selhub J (2007) Folate and vitamin B-12 status in relation to anemia, macrocytosis, and cognitive impairment in older Americans in the age of folic acid fortification. Am J Clin Nutr 85, 193-200.

83. Ray JG, Vermeulen MJ, Langman LJ, Boss SC \& Cole DE (2003) Persistence of vitamin $B_{12}$ insufficiency among elderly women after folic acid food fortification. Clin Biochem 36, 387-391.

84. Brouwer I \& Verhoef P (2007) Folic acid fortification: is masking of vitamin B-12 deficiency what we should really worry about? Am J Clin Nutr 86, 897-898.

85. Liem A, Reynierse-Buitenwerf GH, Zwinderman AH, Jukema JW \& van Veldhuisen DJ (2003) Secondary prevention with folic acid: effects on clinical outcomes. J Am Coll Cardiol 41, 2105-2113.

86. The Heart Outcomes Prevention Evaluation Investigators (2006) Homocysteine lowering with folic acid and B vitamins in vascular disease. N Engl J Med 354, 1567-1577.

87. Wyckoff KF \& Ganji V (2007) Proportion of individuals with low serum vitamin B-12 concentrations without macrocytosis is higher in the post folic acid fortification period than in the pre folic acid fortification period. Am J Clin Nutr 86, 1187-1192.

88. Powers HJ (2007) Folic acid under scrutiny. Br J Nutr 98, 665-666. 
Appendix: Population total folate consumption by age, gender, race/ethnicity and folic acid fortification level

\begin{tabular}{|c|c|c|c|c|c|c|c|c|c|c|c|c|c|c|c|c|}
\hline & \multicolumn{16}{|c|}{ Folate intake ${ }^{\star}$} \\
\hline & \multicolumn{4}{|c|}{ No fortification } & \multicolumn{4}{|c|}{$140 \mu \mathrm{g} / 100 \mathrm{~g} \dagger$} & \multicolumn{4}{|c|}{$350 \mu \mathrm{g} / 100 \mathrm{~g}$} & \multicolumn{4}{|c|}{$700 \mu \mathrm{g} / 100 \mathrm{~g}$} \\
\hline & $\leq 200$ & $201-300$ & $301-400$ & $>400$ & $\leq 200$ & $201-300$ & $301-400$ & $>400$ & $\leq 200$ & $201-300$ & $301-400$ & $>400$ & $\leq 200$ & $201-300$ & $301-400$ & $>400$ \\
\hline \multicolumn{17}{|l|}{ Males } \\
\hline \multicolumn{17}{|c|}{ Non-Hispanic white (\%) } \\
\hline 15-44 years & 19 & 28 & 17 & 36 & 0 & 17 & 23 & 57 & 0 & 3 & 11 & 86 & 0 & 0 & 1 & 99 \\
\hline $45-64$ years & 13 & 21 & 14 & 52 & 3 & 13 & 18 & 66 & 0 & 3 & 9 & 88 & 0 & 0 & 1 & 99 \\
\hline $65+$ years & 17 & 23 & 15 & 45 & 4 & 19 & 21 & 55 & 0 & 5 & 17 & 78 & 0 & 0 & 1 & 99 \\
\hline \multicolumn{17}{|c|}{ Non-Hispanic black (\%) } \\
\hline $15-44$ years & 26 & 46 & 14 & 14 & 5 & 35 & 33 & 27 & 0 & 8 & 28 & 64 & 0 & 0 & 4 & 96 \\
\hline 45-64 years & 41 & 24 & 12 & 23 & 15 & 27 & 21 & 38 & 2 & 11 & 19 & 68 & 0 & 1 & 5 & 94 \\
\hline $65+$ years & 49 & 23 & 10 & 19 & 35 & 20 & 12 & 32 & 26 & 16 & 12 & 46 & 19 & 12 & 10 & 59 \\
\hline \multicolumn{17}{|c|}{ Mexican-American (\%) } \\
\hline 15-44 years & 27 & 35 & 17 & 21 & 2 & 17 & 27 & 54 & 0 & 1 & 6 & 93 & 0 & 0 & 0 & 100 \\
\hline $45-64$ years & 25 & 29 & 16 & 29 & 6 & 23 & 24 & 47 & 0 & 5 & 16 & 78 & 0 & 0 & 2 & 98 \\
\hline $65+$ years & 26 & 28 & 16 & 30 & 13 & 25 & 21 & 41 & 3 & 16 & 20 & 60 & 0 & 4 & 11 & 84 \\
\hline \multicolumn{17}{|c|}{ Females } \\
\hline \multicolumn{17}{|c|}{ Non-Hispanic white (\%) } \\
\hline 15-44 years & 41 & 23 & 5 & 31 & 9 & 32 & 20 & 39 & 0 & 7 & 22 & 71 & 0 & 0 & 1 & 99 \\
\hline $45-64$ years & 28 & 19 & 8 & 46 & 7 & 21 & 16 & 56 & 0 & 5 & 14 & 80 & 0 & 0 & 1 & 98 \\
\hline $65+$ years & 23 & 21 & 8 & 48 & 8 & 25 & 15 & 52 & 0 & 11 & 24 & 65 & 0 & 0 & 5 & 95 \\
\hline \multicolumn{17}{|c|}{ Non-Hispanic black (\%) } \\
\hline 15-44 years & 60 & 18 & 4 & 18 & 31 & 29 & 14 & 26 & 10 & 22 & 20 & 48 & 2 & 8 & 13 & 76 \\
\hline 45-64 years & 52 & 19 & 5 & 24 & 24 & 34 & 14 & 28 & 3 & 23 & 29 & 46 & $\overline{0}$ & 1 & 11 & 88 \\
\hline $65+$ years & 53 & 23 & 7 & 17 & 41 & 35 & 7 & 16 & 11 & 65 & 7 & 16 & 0 & 23 & 61 & 16 \\
\hline \multicolumn{17}{|c|}{ Mexican-American (\%) } \\
\hline $15-44$ years & 63 & 21 & 4 & 12 & 12 & 35 & 25 & 28 & 0 & 6 & 18 & 77 & 0 & 0 & 1 & 99 \\
\hline $45-64$ years & 44 & 21 & 6 & 29 & 25 & 29 & 13 & 33 & 8 & 25 & 22 & 45 & 1 & 8 & 19 & 73 \\
\hline $65+$ years & 30 & 25 & 12 & 33 & 22 & 29 & 15 & 34 & 11 & 31 & 22 & 36 & 2 & 19 & 36 & 43 \\
\hline
\end{tabular}

*Folate intake categories defined by total average folate intake in $\mu \mathrm{g} / \mathrm{d}$.

tStrategies labelled by amount of fortification in $\mu \mathrm{g}$ of folic acid added per $100 \mathrm{~g}$ of enriched grain product. 